\title{
Understanding the Post-Industrial Assembly Line: A Critical Appraisal of the Call Centre
}

Anthony Lloyd - Teesside University

\begin{abstract}
As a relatively new form of service sector employment, call centres have been an important issue in the sociology of work for two decades. This article offers a critical review and appraisal of the existing call centre literature, drawing upon an existing typology classifying call centre research in four categories: characteristics and organisational features; choices and strategies of management; the effect of work on employees; and the response of employees to working conditions. The article also explores recent developments that utilise call centres as a tool to investigate emerging social theories and other sociological concepts.
\end{abstract}

\section{Introduction}

Call centres have been a key site of sociological analysis for over two decades. This paper aims to review and critique existing call centre research, highlighting key debates shaping the literature. Whilst business schools and HR researchers focus on organisational practices and management strategy (Wallace et al 2000, Houlihan 2000, 2002, Robinson and Morley 2006), this article asks how sociology will continue engaging with call centres. Broadly speaking, much call centre literature has been necessarily classificatory (Russell 2008). Given the relative newness of the call centre and early sensationalist headlines about 'electronic sweatshops' (Fernie and Metcalf 1998), research has mostly focused on identifying how they operated and the similarities and differences between sectors, industries, in-house and outsourced organisations (Kinnie et al 2008).

Research has considered the impact of various phenomena including gender (Belt 2002), stress, burnout and turnover (Deery et al 2002), emotional labour (Mulholland 2002), power, surveillance and control (Townsend 2005), teamwork (van den Broek et al 2004), technology (Prichard et al 2014), and geographic location (Richardson and Belt 2001). The specific features of the call centre encourage application of certain analytical tools and concepts such as power and surveillance or gender yet few studies attempt to place call centres within a political-social-economic context and much research appears to leave the 
call centre in a vacuum (Ellis and Taylor 2006). Meanwhile, some studies have attempted to investigate or reinvigorate theoretical frameworks within the sociology of work in the context of call centre research (Mulholland 2004). This paper suggests the call centre remains important in connecting the workplace with key sociological issues and theories as well as a case study for exploring new configurations of work in contemporary society, rather than maintaining a narrow focus on the call centre industry. For the call centre to remain a site of sociological investigation, it must become the context for application of a range of analytical tools and concepts rather than the primary focus of research. In a labour market broadly characterised by the growth of service work (Lloyd 2013), the call centre can serve a sociological purpose.

In 2002, Deery and Kinnie offered an evaluation of existing call centre literature. They identified four key themes that typified much of the early research: characteristics and organisational features of call centre work; choices and strategies of management; the effect of work on employees; and the response of employees to working conditions (Deery and Kinnie 2002). In bringing call centre literature up to date, these categories form the basis of this paper. The concluding section contemplates new developments in call centre research and suggestions for the future.

\section{Characteristics and Organisational Features of Call Centre Work}

Some agreement exists regarding the characteristics of a call centre (Russell 2008). They have largely been portrayed as low-paid, stressful working environments where workers lack autonomy and control whilst providing 'emotional labour'. Call centres utilise information and communication technology (ICT) to automatically route calls to Customer Service Representatives (CSRs) whilst managers maintain the ability to conduct electronic surveillance on employees who perform routine functions via the 'assembly line in the head' (Taylor and Bain 1999, Ball and Margulis 2011).

Studies have attempted to identify generic 'workflows' (Taylor et al 2002) or 'call configurations' (Glucksmann 2004) that typify the call centre work process. Taylor et al (2002) identify nine workflows on the spectrum of call quantity versus call quality (see below) and comprise issues including control, targets, pace of work, breaks, and call 
monitoring. Employee responses indicate that even workflows designed to emphasise quality customer service rather than increased call quantity are experienced by CSRs as controlling and lacking autonomy; needless to say, workflows emphasising quantity are keenly felt as controlling and lacking autonomy. The authors predicted that call centres would continue moving towards greater routine, division of labour and target-driven processes as an efficient, cost-effective strategy rather than a quality-driven process, a prediction borne out by subsequent research (see Lloyd 2013, McFadden 2015).

Glucksmann (2004) analysed call centres according to a 'Total Social Organisation of Labour' (TSOL). Placing call centres in a process relational to other functions in the overall configuration of production, distribution, exchange and consumption attempts to show the diversity of call centre configurations. By looking at the call centre in a wider context of circulation, Glucksmann attempts to move beyond the isolated unit of production to place call centres in a more sociological context. Taylor and Bain (2007) offer a thoroughgoing critique suggesting her 'shift of prism' remains too abstract and fails to recognise the call centre as part of capitalist political economy. For example, Glucksmann argues outsource companies 'stand-alone' as autonomous businesses subcontracted by sellers. As others correctly demonstrate (Taylor and Bain 2007, Kinnie et al 2008), outsource companies are uniquely pressured by commitments and service level agreements with sellers which significantly impacts upon their work processes and management strategy and autonomy.

Electronic monitoring has been a popular area of research largely due to the original interpretation of call centres as a modern manifestation of Foucault's 'total' institution (Fernie and Metcalf 1998). Subsequent studies have rejected this (Taylor and Bain 1999) and highlighted the complicated role of ICT in creating work processes and surveillance strategies used by call centre managers (Bain and Taylor 2000, Townsend 2005). Bain and Taylor (2000) suggest that while technology can monitor employee performance to an unprecedented degree, it still requires human intervention and management. Whilst not a 'total institution', employees nevertheless find themselves constrained by an electronic system controlling their pace of work. 
The level of skill required has caused debate (see Belt 2002, Mulholland 2002, Lloyd and Payne 2009). Belt (2002) suggests women are largely recruited to call centres due to gendered 'social skills' (also Belt et al 2002) associated with interpersonal communication, personality, patience, problem-solving, empathy and emotional labour (see also Taylor and Tyler 2000). In a broader context, most new jobs in Britain are either in high-skilled, wellpaid emerging industries or in low-skilled, low-paid service work. Taylor and Bain's work $(1999,2002,2003,2005)$ noted that call centres are complicated; employees are not unthinking automatons, but require competence with technology, product knowledge and interpersonal social skills. However, call centre jobs do not demand specific qualifications or indeed a great deal of training. Lloyd and Payne (2009) suggest that 'skilled work' needs to be re-evaluated in today's knowledge economy before determining skill levels required for call centre work.

Outsourcing call centre functions to third parties (Kinnie et al 2008) and overseas subcontractors (Taylor and Bain 2005, Patel 2010) is a prominent feature of the industry. Taylor and Bain (2005) delineate the rapid growth of Indian call centres whilst others highlight outsourcing to Ireland, the Philippines and elsewhere (Mulholland 2004, Kinnie et al 2008). Call centre work in India is regarded as more prestigious than in the UK although it often clashes with normative cultural practices and hierarchies, particularly around gender and class (see Patel 2010, Sarkar and Charlwood 2014). Placing outsourcing in a macro-level context, the liberalisation of trade, capital and communications across the western world facilitates movement towards greater efficiency, productivity and capital accumulation (Taylor and Bain 2005, Ellis and Taylor 2006). It is cost-effective to outsource routine functions to call centres with lower overheads and labour costs, both at home and overseas. There is scope to consider the future of call centre work in Britain and India through engagement with Brown et al's (2011) 'global auction' of education, skills and jobs; the traditional dilemma of UK firms choosing between cost and quality (outsourcing for costeffectiveness or remaining in-house for higher skill level) is removed through recent and growing Indian and Chinese investment in education and training. Firms can now outsource to India knowing they will receive cost-effectiveness and high quality. What are the future implications for UK-based service work? 


\section{Choices and Strategies of Management}

The primary debate amongst call centre scholars concentrates on quantity versus quality (Robinson and Morley 2006). Repeated descriptions of call centres as an efficient, logical, cost-effective method of rationalising customer service functions suggests management focus on productivity (ibid). The literature abounds with a dichotomy between management pronouncements towards service quality and customer satisfaction and an economic logic requiring efficiency, target attainment and productivity (Taylor and Bain 1999, Robinson and Morley 2006). Ambition towards call quality is not a cynical attempt at masking the reality of quantity-driven work processes, rather a genuine aspiration too often a casualty of the cold logic of efficiency; Robinson and Morley (2006) found an overwhelming response in favour of quality service routinely undermined by quantitative measurement of KPIs. The ability to measure certain indicators prefigures a compulsion towards measurement and reliance on quantifiable outputs as a gauge of performance and customer service. Examples repeatedly point to processes, workflows and management practices expounding the need for quality but often receding against the need to satisfy clients (Kinnie et al 2008, Lloyd 2013, 2016a) or meet targets (Bain et al 2002).

Deery and Kinnie (2002) argue that multiple forms of control exist in call centres, not simply an updated Tayloristic scientific management (Bain et al 2002). The literature supports this although most research focuses on labour process and automated call routing (Deery et al 2010). Management control is also shown to exist through cultural manipulation in the form of recruiting employees with particular skills or values (Callaghan and Thompson 2002, van den Broek 2004) and training regimes designed to inculcate company values and ethics (Townsend 2007). Fleming and Sturdy (2011) identify a third strategy encouraging employees to 'be yourself' at work; demonstrating individualism through dress and manner, infusing their work with distinctive personality traits and regarding work as a 'fun' place to be. This masks a control strategy that ensures the work process is followed, labour power converts into surplus value, and resistance is muted (ibid).

\section{Effects of Work on Employees}

The impact of call centre work on employees is an oft-recited catalogue of physical and emotional hardship (Deery et al 2002, Holman 2003, Holdsworth and Cartwright 2003, Rose 
and Wright 2005, Wegge et al 2010). Taylor et al (2003) found the work process incongruous with good health and well-being. Employees routinely reported suffering from a range of issues including stress, headaches and physical problems such as sore eyes, shoulders and necks. This finding is repeated across subsequent research (Tuten and Niedermeyer 2004, Witt et al 2004, Holman 2003, Holdsworth and Cartwright 2003, Kjellberg et al 2010, Deery et al 2010). Whilst all literature broadly agree these negative effects result from the labour process, most conclude that different HR strategies would resolve the problem (see Holman 2003, Kjellberg et al 2010). A broader appreciation of the political-economic context that spawned and shaped call centres (see Ellis and Taylor 2006) would demonstrate that management and HR practice is fashioned by factors beyond their control; efficiency, targets and productivity (Bain et al 2002) actively influence HR and management strategy in a competitive market. Wallace et al (2000) detail a 'sacrificial' HR strategy whereby intensive work processes remain unchanged whilst exhausted staff are incorporated into business plans; high turnover is factored into recruitment policies that continually replace burned out staff (see Lloyd 2013). The concentration of call centre research within business and management schools misses this crucial broader analysis that sociology is uniquely placed to offer.

Taylor and Tyler (2000) operationalise Hochschild's (2003) concept of emotional labour to consider the gendered division of labour within the service sector. Their mid-1990s study incorporated an embryonic call centre and offers a good example of sociological research into a particular analytical concept rather than a narrow focus on the call centre industry. Taylor and Tyler (2000; see also Taylor 1998) demonstrate the use of emotional labour in service work, the belief that emotional labour is 'women's work', and the connection between emotional management in the production of value and performance related pay. Taylor and Bain (1999) and others (Mulholland 2002) also lucidly convey the impression that interactive service work places emotional pressure on employees forced to suppress their own feelings.

The stress, burnout and exhaustion demonstrated in a range of studies (Deery et al 2002, 2010, Lloyd 2013) indicate the demands of call centre work negatively affect individuals required to perform 'affective labour'. Wegge et al (2010) consider 'emotional dissonance', 
the distance between how someone says they feel and how they actually feel. Whilst recognising the requirement to perform emotional labour, their conclusions appear to imply that individuals predisposed to negative feelings and emotions are ill-suited to call centre work. Although undoubtedly true, this absolves the work process of blame; the individual becomes responsible for their psychic makeup and coping strategies rather than being subject to stressful working environments that challenge even the most optimistic souls.

Researchers from a sociological and psychological perspective focused on empowerment, satisfaction, and quality of life discourses (Holdsworth and Cartwright 2003, Rose and Wright 2005, Hannif et al 2008). Others considered call centres in terms of a 'psychological contract' between employees and employers (Cross et al 2010, Chambel and Alcover 2011). Temporary employees utilise a 'transactional contract' that is economic-oriented resulting in little further investment by employer or employee. Breaking this contract is relatively easy and one explanation for high turnover. Chambel and Alcover (2011) suggest permanent workers reported a 'relational' contract based on identifying prospects for promotion and the possibility of a call centre career. However, as Belt (2002) identified, a relatively flat hierarchy limits opportunities for promotion.

\section{Response of Employees}

Are call centres sites of collective resistance or do labour processes designed to divide a workforce into individual units of production engender individualised responses? Inheriting the debate within the sociology of work between labour process theory and its attendant critique of the 'missing subject', call centre research has looked at the response of employees through this prism (Taylor and Bain 1999, Mulholland 2004, Townsend 2005). Taylor and Bain (1999) rejected Fernie and Metcalf's (1998) Foucauldian interpretation of call centre monitoring and demonstrated ways employees find space to resist an automated work process that can monitor employees intensively but still requires a human to identify attempts at fiddling the system.

Mulholland (2004) reveals multiple avenues of resistance including dropping calls, cutting off customers, manipulating electronic surveillance systems to give the impression CSRs are working, and ultimately quitting. Taylor and Bain (2003) found humour as a subversive act 
that undermines management authority. Townsend (2005) suggests grouping employees into teams can produce cohesive units that support one another and resist management where possible. Winiecki $(2004,2007)$ and McCabe (2004) approach resistance from the perspective of subjectivity. Both contemplate how the subject is created and modified by a work process that seemingly removes space for individuals to function as individuals; Winiecki sees 'shadowboxing with the data' as a way to assert one's subjectivity, whilst McCabe sees subjectivity emerging through employee rejection of normative management narratives of an unproblematic 'present' compared with a troublesome 'past' ("things used to be bad but now they're ok...").

Trade unions have a patchy relationship with call centres but appear to have made some gains (Bain and Taylor 2002, Taylor and Bain 2001). Internationally, the picture is as varied as it is in the UK (Sarkar and Charlwood 2014, Holst 2008). Bain et al (2002) suggest that call centres with strong and active union participation stem from sectors with a history of involvement in the labour movement before companies streamlined customer service functions. The existing ethos of collective bargaining and union activity carried over into the call centre and facilitated negotiation on behalf of employees. Meanwhile, some research indicates call centres in industries with little or no union background, or with employees possessing no institutional memory of collective bargaining, result in trade unions struggling to make gains or staff failing to connect with union narratives (Lloyd 2013). Taylor and Bain (2001) highlight that management moved the 'frontier of control' within call centres so whilst unions discuss issues around pay, working conditions at the point where surplus value is created remain out of scope; the 'point of production' remains under management control. Cultural differences exist when considering call centres in an international perspective; Sarkar and Charlwood (2014), in a comparison between UK and Indian call centres, found cultural attitudes unlikely to constrain or facilitate union efforts to organise; instead, the institutional context was more important than general collectivist values.

Utilising the labour process as a site for resistance, research suggests that recognition of oppressive working practices can lead to formal opposition to management (Taylor and Bain 1999, Brophy 2010). Mulholland (2004) employs the concept of a 'collective worker' to identify informal networks of resistance emerging from the acknowledgement of 
exploitation yet to crystallise into formal open resistance. My recent work (2016b) argues that call centre resistance offers an insight into the workings of ideology more akin to 'cynical distance' than 'false consciousness'; call centre workers are not blind to their exploitation, they are acutely aware of the conditions of their existence but act as if they are not ("I know things are bad but I do it anyway..."). In considering ideology as a fetishistic disavowal, working at the level of action instead of thought, this asks sociology to reconsider resistance and critically reflect on evidence from the call centre in a broader analysis of capitalism and ideology. If the call centre literature highlights opportunities for resistance, why do conditions, pay and working experiences largely remain unchanged?

\section{New Ways of Seeing the Call Centre}

Following twenty years of exhaustive investigation, there is a declining appetite for call centre research. An inevitable limit exists on the relevance of research investigating intricacies of labour processes, management and employee attitudes, and organisational methodologies within call centres. Unless a fundamental shift in practice occurs, is all that remains to cover old ground or highlight differences between institutions? Up to now, call centre research has performed an important task in outlining working practices, management strategies and employee experiences in that environment. As described above, the research on resistance is largely misdirected in terms of analysis but crucial in shining a light on practice and experience in the workplace. Despite limitations in the breadth of analysis and willingness to connect the call centre industry with wider socialpolitical-economic themes and issues, there is scope for future research that shifts focus and concentrates on what call centre data may represent.

Some of the research mentioned above examines the call centre in a sociological context; applying distinct analytical tools to studies of workplaces including the call centre (Taylor and Tyler 2000, Glucksmann 2004), framing call centres in a broader political-economic context (Taylor and Bain 1999, Ellis and Taylor 2006), or applying existing theoretical perspectives to the call centre in an attempt to identify lines of convergence and divergence with previous organisational cultures and practices (Mulholland 2004). A major proportion of call centre research emanates from within business and management schools therefore 
has limited application to sociologists keen to investigate analytical connections between concepts and daily life or connect experiences at a micro, mezzo and macro levels.

Recent evidence suggests potential for using call centres as the context in which broader issues and theory are tested (Brophy 2010, 2015, McFadden 2015, Brannan 2015). Connecting the micro and mezzo of subjective experience and organisational practice with the macro of political economy opens up possibilities for broader application. Brophy (2010) has used call centres as a lens through which to test Jodi Dean's (2009) 'communicative capitalism', recognising a natural connection between the call centre and Dean's assertion that the economy has increasingly incorporated and become dependent upon the 'proliferation, distribution, acceleration and intensification of communicative access and opportunity' (Dean 2009: 17 cited in Brophy 2010: 471). As communicative capitalism signifies a shift towards ongoing information exchange between customers and corporations, the call centre mediates this relationship. Communicative labour facilitates communicative capitalism. Brophy also introduces an autonomist Marxist analysis, looking at the ineluctably conflictual relationship between labour and capital and labour's resistance and search for autonomy within this relation. It offers a sophisticated theoretical framework within which to consider the nature of call centre work generally and the space for labour resistance within organisations.

Brannan (2015) has recently applied Bourdieu's 'symbolic violence' to employee retention strategies within call centres. Brannan highlights the production and reproduction of 'structures of subordination' within call centres that he argues reflect Bourdieu's symbolic violence; the legitimation of particular processes that reach the level of 'doxa', simply an unquestioning acceptance of 'the way things are'. Those employees who remain with the company engage in collusion and consent with the dominant ethos, misrecognising and actively reinforcing its legitimacy. Brannan's analysis is a potential starting point for future research on the workplace; do structures of subordination reinforced by 'symbolic violence' exist in other industries? Those interested in the sociology of work could benefit from engagement with such analytical tools. Paul McFadden's (2015) recent research uses call centres as a site for investigation of 'body work' and understanding bodies under capitalism. 'Body work' represents 'labour that utilizes the embodied properties of workers' (2015: 91), 
how work inscribes itself on the body. As political economy shifts towards 'cognitive capitalism', this has a corporeal effect; workers embody labour power and McFadden is interested in determining how capitalism produces 'capitalistic subjects' who produce value through the efficient function of body work. This analysis takes labour process theory, emotional labour, and aesthetic labour theories and advances the discussion by integrating Marxist social theory within a particular site of analysis, the call centre.

Brophy (2015) also recently identified valuable work across recent call centre literature focusing on identity and subjectivity; connecting sociological investigation of the subject with conditions of employment. My own research uses call centres as a starting point for discussion of identity, subjectivity, ideology, and the idea of progress (Lloyd 2012, 2013, 2016a, 2016b). The interplay between subjectivity and social structures is often evident in workplace sociology (Blauner 1964, Beynon 1973 for examples). The call centre offers a continuation of this examination of the dialectical relationship between subject and structure but also requires theoretical engagement for explanatory purposes. The analytical tools and theoretical frameworks mentioned in this section represent several potential ways forward.

\section{Conclusion}

It could be argued that call centre literature has saturated journal output over the last twenty years resulting in a waning appetite for further study. However, thought-provoking research continues to appear (Brophy 2010, McFadden 2015). The call centre still has a lot to say about labour relations, organisational practice and structure, and employee attitudes. Whilst major changes in the nature of call centres continue to be analysed, the classificatory groundwork serves as solid bedrock from which to embark on wider sociological analysis. The more sophisticated research has identified the unique socio-economic-political factors that presented organisations with the means and will to centralise customer service functions in order to pursue efficiency, targets, productivity and profit in a competitive market (Ellis and Taylor 2006).

Since the financial crisis of 2008, the political, economic and social contours of Western society have changed dramatically and the effects of widespread upheaval, recession, 
austerity, technological development continue to impact at mezzo and micro level (see Lloyd 2013, 2016a, 2016b). Sociology, using the groundwork undertaken by call centre researchers, can and should use the call centre as a jumping-off point for research that looks at the impact of social change on individual lives and organisations. It should also use the call centre as a site against which to test advances and developments in social theory, for example Enda Brophy's (2010) analysis of 'communicative capitalism' or my deployment of a 'reversal of ideology' to consider the nature and impact of workplace resistance (2016b). Call centres, and their employees, can be a microcosm of fundamental sociological issues facing contemporary society. Future work on, for example, youth transitions and identity in an age of austerity, set against the backdrop of low-paid, stressful, exploitative service work in an industry recognised for its flat hierarchy and limited opportunities for advancement would operationalise the call centre as a site for sociological analysis. This is a challenge for sociologists interested in call centres and one I hope is accepted, moving sociological theory, research and debate forward.

\section{Reference List}

Bain, P., et al (2002) "Taylorism, targets and the pursuit of quantity and quality by call centre management" in New Technology, Work and Employment. 17(3) 170-185.

Bain, P. and Taylor, P. (2000) “Entrapped by the 'electronic panoptican'? Worker resistance in the call centre" in New Technology, Work and Employment. 15(1) 2- 18.

Bain, P. and P. Taylor (2002) 'Ringing the changes? Union recognition and organisation in call centres in the UK finance sector' Industrial Relations Journal 33(3) 246-261

Ball, K.S. and Margulis, S.T. (2011) "Electronic monitoring and surveillance in call centres: A framework for investigation" in New Technology, Work and Employment. 26(2) 113-126.

Belt, V. (2002) "A female ghetto? Women's careers in call centres" in Human Resource Management Journal. 12(4) 51-66.

Belt, V., Richardson, R. and Webster, J. (2002) "Women, social skill and interactive service work in telephone call centres" in New Technology, Work and Employment. 17(1) 20-34.

Beynon, H. (1973) Working for Ford. London: Penguin.

Blauner, P. (1964) Alienation and Freedom. London: University of Chicago Press. 
Brannan, M. (2015) “'You're not going anywhere': Employee retention, symbolic violence and the structuring of subordination in a UK-based call centre" in The Sociological Review. 63(4) 801-819.

Brophy, E. (2010) "The subterranean stream: Communicative capitalism and call centre labour" in Ephemera: Theory \& Politics in Organization. 10(3/4) 470-483.

Brophy, E. (2015) "Revisiting the Digital Assembly Line: New Perspectives on Call Centre Work" in Labour/Le Travail. 75 211-230.

Brown, P., Lauder, H. and Ashton, D. (2011) The Global Auction. Oxford: University Press.

Callaghan, G. and Thompson, P. (2002) “'We recruit attitude': The selection and shaping of routine call centre labour" in Journal of Management Studies. 39(2) 233-254.

Chambel, M.J. and Alcover, C.M. (2011) "The psychological contract of call centre workers: Employment conditions, satisfaction and civic virtue behaviours" in Economic and Industrial Democracy. Published online $6^{\text {th }}$ January 2011.

Cross, C., Barry, G. and Garavan, T.N. (2008) "The psychological contract in call centres" in Journal of Industrial Relations. 50(2) 229-242.

Dean, J. (2009) Democracy and Other Neoliberal Fantasies: Communicative Capitalism and Left Politics. London: Duke University Press.

Deery, S. and Kinnie, N. (2002) "Call centres and beyond: A thematic evaluation" in Human Resource Management Journal. 12(4) 3-13.

Deery, S., Iverson, R. and Walsh, J. (2002) "Work relationships in telephone call centres: Understanding emotional exhaustion and employee withdrawal" in Jounral of Management Studies. 39(4) 471-496.

Deery, S., Iverson, R. and Walsh, J. (2010) "Coping strategies in call centres: Work intensity and the role of co-workers and supervisors" in British Journal of Industrial Relations. 48(1) 181-200.

Ellis, V. and Taylor, P. (2006) “'You don't know what you've got till it's gone': Recontextualising the origins, development and impact of the call centre" in New Technology, Work and Employment. 21(2) 107-122.

Fernie, S. and Metcalf, D. (1998) (Not) Hanging on the Telephone: Payment Systems in the New Sweatshops. London: Centre for Economic Performance. 
Fleming, P. and Sturdy, A. (2011) “'Being yourself' in the electronic sweatshop: New forms of normative control" in Human Relations. 64(2) 177-200.

Glucksmann, M. (2004) "Call configurations: Varieties of call centre and divisions of labour" in Work, Employment and Society. 18(4) 795-811.

Hannif, Z., Burgess, J. and Connell, J. (2008) "Call centres and the quality of work life: Towards a research agenda" in Journal of Industrial Relations. 50(2) 271-284.Hochschild, A. R. 2003. The Managed Heart: Commercialization of Human Feeling. London; University of California Press.

Holdsworth, L. and Cartwright, S. (2003) "Empowerment, stress and satisfaction: An exploratory study of a call centre" in Leadership and Organization Development Journal. 24(3) 131-140.

Holman, D. (2003) "Phoning in Sick? An overview of employee stress in call centres" in Leadership and Organization Development Journal. 24(3) 123-130.

Holst, H. (2008) "The political economy of trade union strategies in Austria and Germany: The case of call centres" in European Journal of Industrial Relations. 14(1) 25-45.

Houlihan, M. (2000) "Eyes wide shut? Querying the depth of call centre training" in Journal of European Industrial Training. 24(2) 228-240.

Houlihan, M. (2002) "Tensions and variations in call centre management strategies" in Human Resource Management Journal. 12(4) 67-85.

Kinnie, N., Purcell, J. and Adams, M. (2008) "Explaining employees' experience of work in outsourced call centres: The influence of clients, owners and temporary work agencies" in Journal of Industrial Relations. 50(2) 209-227.

Kjellberg, A. et al (2010) "Stress, energy and psychosocial conditions in different types of call centres" in Work. 36(1) 9-25.

Lloyd, C. And Payne, J. (2009) "'Full of sound and fury, signifying nothing': Interrogating new skill concepts in service work - the view from two UK call centres" in Work, Employment and Society. 23(4) 617-634.

Lloyd, A. (2012) "Working to Live, Not Living to Work: Work, Leisure and Youth Identity Among Call Centre Workers in North East England" in Current Sociology. 60(5) 619-635.

Lloyd, A. (2013) Labour Markets and Identity on the Post-Industrial Assembly Line. Farnham: Ashgate. 
Lloyd, A. (2016a) "Efficiency, productivity and the 'comfort break': Reflections on the nature of progress from the call centre floor" in The Sociological Review.

Lloyd, A. (2016b) "Ideology at Work: Reconsidering ideology, the labour process and workplace resistance." In International Journal of Sociology and Social Policy.

McCabe, D. (2004) "'A Land of Milk and Honey'? Reengineering the 'Past' and 'Present' in a call centre" in Journal of Management Studies. 41(5) 827-856.

McFadden, P. (2015) "The Production of Politics in Front-Line Service Work: "Body Work" in the Labour Process of the Call Centre Worker" in Global Society. 29(1) 89-106.

Mulholland, K. (2002) "Gender, emotional labour and teamworking in a call centre" in Personnel Review. 31(3) 283-303.

Mulholland, K. (2004) “Workplace resistance in an Irish call centre: Slammin', scammin', smokin' and leavin'" in Work, Employment and Society. 18(4) 709-724.

Patel, R. 2010. Working the Night Shift: Women in India's Call Center Industry. Stanford, CA; Stanford University Press.

Prichard, J. et al (2014) "Trusting technical change in call centres" in Work, Employment and Society. 28(5) 808-824.

Richardson, R. and Belt, V. (2001) "Saved by the bell? Call centres and economic development in less favoured regions" in Economic and Industrial Democracy. 22(1) 67-98.

Robinson, G. and Morley, C. (2006) "Call centre management: Responsibilities and performance" in International Journal of Service Industry Management. 17(3) 284-300.

Rose, E. and Wright, G. (2005) "Satisfaction and dimensions of control among call centre customer service representatives" in The International Journal of Human Resource Management. 16(1) 136-160.

Russell, B. (2008) "Call centres: A decade of research" in International Journal of Management Reviews. 10(3) 195-219.

Sarkar, S. and Charlwood, A. (2014) "Do cultural differences explain differences in attitudes towards unions? Culture and attitudes towards unions among call centre workers in Britain and India" in Industrial Relations Journal. 45(1) 56-76.

Taylor, P. and Bain, P. (1999) "'An assembly line in the head': Work and employee relations in the call centre" in Industrial Relations Journal. 30(2) 101-117.

Taylor, P. and Bain, P. (2001) “Trade unions, workers' rights and the frontier of control in UK call centres' in Economic and Industrial Democracy. 22(1) 39-66. 
Taylor, P. and Bain, P. (2003) "'Subterranean worksick blues': Humour as subversion in two call centres" in Organization Studies. 24(9) 1487-1509.

Taylor, P. and Bain, P. (2005) “'India calling to the far away towns': The call centre labour process and globalization" in Work, Employment and Society. 19(2) 261-282.

Taylor, P. and Bain, P. (2007) "Reflections on the call centre - a reply to Glucksmann" in Work, Employment and Society. 21(2) 349-362.

Taylor, P. et al (2002) "Work organization, control and the experience of work in call centres" in Work, Employment and Society. 16(1) 133-150.

Taylor, P. et al (2003) "'A unique working environment': Health, sickness and absence management in UK call centres" in Work, Employment and Society. 17(3) 435-458.

Taylor, S. (1998) "Emotional Labour in the New Workplace" in Thompson, P. and Warhurst, C. (Eds.) Workplaces of the Future. London: Macmillan.

Taylor, S. and Tyler, M. (2000) "Emotional Labour and Sexual Difference in the Airline Industry" in Work, Employment and Society. 14(1) 77-95.

Townsend, K. (2005) "Electronic surveillance and cohesive teams: Room for resistance in an Australian call centre?" in New Technology, Work and Employment. 20(1) 47-59.

Townsend, K. (2007) "Recruitment, training and turnover: Another call centre paradox" in Personnel Review. 36(3) 476-490.

Tuten, T.L. and Niedermeyer, P.E. (2004) "Performance, satisfaction and turnover in call centres: The effects of stress and optimism" in Journal of Business Research. 57(1) 26-34.

Van den Broek, D. (2004) “'We have the values': Customers, control and corporate ideology in call centre operations" in New Technology, Work and Employment. 19(1) 2-13.

Van den Broek, D., Callaghan, G. and Thompson, P. (2004) "Teams without teamwork? Explaining the call centre paradox" in Economic and Industrial Democracy. 25(2) 197-218.

Wallace, C.M., Eagleson, G. and Waldersee, R. (2000) "The sacrificial HR strategy in call centers" in International Journal of Service Industry Management. 11(2) 174-184.

Wegge, J., van Dick, R. and von Bernstorff, C. (2010) "Emotional dissonance in call centre work" in Journal of Managerial Psychology. 25(6) 596-619.

Winiecki, D.J. (2004) "Shadowboxing with data: Production of the subject in contemporary call centre organisations" in New Technology, Work and Employment. 19(2) 78-95.

Winiecki, D.J. (2007) "Subjects, subjectivity and subjectification in call centre work: The doing of doings" in Journal of Contemporary Ethnography. 36(4) 351-377. 
Witt, L.A., Andrews, M.C. and Coulson, D.S. (2004) “When conscientiousness isn't enough: Emotional exhaustion and performance among call center customer service representatives" in Journal of Management. 30(1) 149-160. 